\title{
Research on Target Costing: Past, Present and Future ${ }^{1}$
}

\author{
Marcel Clermont \\ m.clermont@tu-braunschweig.de \\ Heinz Ahn \\ hw.ahn@tu-braunschweig.de
}

Institute of Business Accounting and Management Control, Technische Universität Braunschweig, Fallersleber-Tor-Wall 23, 38100 Brunswick, Germany

\author{
Stephan Schwetschke \\ stephan.schwetschke@volkswagen.de \\ Volkswagen AG, Letter Box 011/1527, 38436 Wolfsburg, Germany
}

\begin{abstract}
Although target costing is an extensively studied topic in the management accounting literature, a holistic investigation into its methodological development is missing. Therefore, an extensive state-of-the-art analysis is conducted that focuses on articles in highly rated journals. We determine nine distinct research streams that encompass further developments of the traditional target costing methodology. By grouping these streams into three research scopes, we outline the achieved progress as well as remaining tasks for further enhancements. Due to the abundance of these tasks, we align them with six future themes of management accounting that we identified as being particularly influential to target costing. As a result, six promising topics for researchers to advance target costing are determined. Additionally, our findings reveal to managers of which issues they should be particularly aware with respect to the performance of their target costing processes.
\end{abstract}

Keywords

Target Costing, Cost Management System, Literature Review, Future Topics

\footnotetext{
${ }^{1}$ We would like to thank two anonymous reviewers whose comments helped us to improve our article substantially.
} 


\section{Introduction}

Cost accounting and cost management systems are the basis for decisions in many fields of business administration. In their current state-of-the-art paper about the history and future of such systems, Pfaff and Trossmann (2016) state amongst others that cost management and decentralised regulation based on cost information will play an important role in the business administration research. Due to significant changes in business and its environment, the existing cost management systems need fundamental enhancements. As such a system, we focus on target costing, which centres on planning and realising target costs to optimise the ratio between relevant product cost factors during the product development process (Hibbets et al. 2003; Nicolini et al. 2000). Since its inception in the early 1960s (Albright and Lam 2006; Hibbets et al. 2003), target costing has rapidly become an established topic in research and practice. Various empirical studies verify target costing's current world-wide application. For example, it has been used in $78 \%$ of Finish forest, metal and electronics companies (Hyvönen 2005) as well as in 84 \% of US-American (Fullerton and McWatters 2004) and in $89 \%$ of Italian manufacturing companies (Cinquini and Tenucci 2010).

Although a great variety of characteristics is subscribed to target costing, it is widely agreed that (1) market orientation, (2) early cost management and (3) cooperative efforts are its main characteristics (see, e.g., Chen et al. 1997; Everaert and Swenson 2014; Ewert and Ernst 1999). First, due to the initial question of target costing, which is "What is a product allowed to cost?" (Flik et al. 1998; Hoffjan 1994; Seidenschwarz 2003), market cost information assumes the central role for cost-efficient product development (Everaert and Swenson 2014; Ewert and Ernst 1999). Second, an emphasis is put on cost management during (early) product development. In this phase, the greatest leeway for cost improvements exists (Fischer and Schmitz 1994; Park et al. 2016), and the future performance as well as profitability of any product are widely determined (Ax et al. 2008; Ibusuki and Kaminski 2007). Third, cooperative efforts of a wide range of specialists from different business areas are required to achieve challenging target costs (Everaert et al. 2006; Roslender and Hart 2002).

On the one hand, target costing is subject to various critiques. For example, it is argued that target costing generally necessitates a high degree of coordination of all involved business areas and members (Steinhoff and Trommsdorff 2008). Also, its proliferating complexity parallel to product sophistication is criticised (Horváth et al. 2015). In regard to target cost calculation, voices of concern emphasise an underlying hidden difficulty that, e.g., stems from uncertain information (Ewert and Wagenhofer 2014). On the other hand, a series of approaches have been proposed to resolve drawbacks due to methodological deficiencies and to further extend the basic target costing concept. Both the critical and the methodological contributions have led to a huge number of published studies in the domain of target costing. Against this background, we raise the following research question: 


\section{$R Q$ 1: To what extent has target costing's methodology been developed further?}

Properly addressing the methodological deficiencies of target costing is a central means for fruitful on-going target costing research. The challenge here is to focus on those research areas that are and will be of high relevance to theory and practice. Therefore, our second research question is:

$R Q$ 2: What are highly relevant prospective directions to advance target costing methodologically in the future?

Until today, at least two papers exist that give a comprehensive overview in regard to target costing: Ansari et al. (2007) and Kajüter (2013). Ansari et al. (2007) synthesised English- and Japanese-speaking literature from 1995 to 2005. They focus on methodological aspects and use the life-cycle of management practice as a framework to structure the literature as well as to develop areas for future research. Kajüter (2013) analyses English- and Germanspeaking literature on target costing. He mainly investigates references concerning the different applications of target costing in companies. In addition to these two studies, the contribution of our in-depth study includes four elements:

- A systematic, reproducible state-of-the-art research resorting to English- and Germanspeaking literature within an enlarged timeframe that ranges from 1988 to 2016;

- A clear focus on target costing's methodology, i.e., its technical aspects. Key areas in which target costing has been methodologically developed further are highlighted and, in a comprehensible manner, remaining research gaps are revealed;

- An evaluation to what extent future themes of management accounting are decisive for methodological advancements of target costing to defend its practical appeal;

- An integration of requirements from academia and organisational practice to guide upcoming research towards highly fruitful research gaps that will likely unfold and be of relevance for target costing in the future.

While our study primarily will be of interest for cost management researchers, our findings concerning meaningful enhancements of target costing in particular are also relevant for researchers in other areas of business administration. Points of reference are, e.g., risk management to include volatile measures, sustainability management to integrate the respective three-pillar model and general management to contribute knowledge about team and learning processes. Hence, new possibilities will arise to make concepts, instruments and approaches of business administration fruitful for an improved target costing.

Our paper is structured as follows: Section 2 introduces the process and methodological deficiencies of traditional target costing as well as a discussion of its value. RQ 1 is addressed in Section 3. We systematically select and analyse 90 high-quality journal articles that portray 
the state-of-the-art of target costing's developments. On this basis, we reveal multiple, partly or completely unresolved deficiencies that constitute a comprehensive research agenda for upcoming scientific studies. Section 4 is devoted to RQ 2. Referring to two large-scale empirical studies about future themes for management accounting, we identify relevant directions to advance target costing in the future. Section 5 discusses the results and limitations.

\section{Traditional target costing}

Target costing emerged as a business practice in the Japanese automotive industry (Albright and Lam 2006; Hibbets et al. 2003) and then spread to industries all over the world (Nicolini et al. 2000). While aligning original Japanese descriptions, e.g., from Kato (1993), to respective cultural conditions, this process of diffusion led to a breadth of context- and countrydependent descriptions of target costing. As therefore no all-encompassing and united understanding exists (Götze and Linke 2008), we focus on widespread, generic conceptions, which we describe in the following under the terminus "traditional target costing".

\subsection{Target costing process}

The traditional target costing process can be separated into five distinct steps, each of which needs specific information (see the upper part of Figure 1). During the step of target cost definition, most prominently, five different approaches can be used to calculate costs: Market into Company and Out of Competitor as two market-oriented calculation approaches, Out of Company and Out of Standard Costs as two internally-oriented calculation approaches and a hybrid approach termed Into and Out of Company (for a detailed description of the five approaches, see, e.g., Brünger and Faupel 2010, Cooper and Slagmulder 1999, Freidank and Zaeh 1997). With all these approaches, in addition to target costs for a single unit, also total target costs can be ascertained; these total target costs are allowed to accrue throughout all periods of the product development and market phase (Gagne and Discenza 1995; Götze and Linke 2008; Krapp and Wotschofsky 2000).

During the target cost decomposition step, initially abstract product target costs are broken down into cost objectives for product functions, components and ultimately single parts (Cooper and Slagmulder 1999; Götze 1993). Two methods are mainly considered: the function-oriented method and the component allocation method (for a detailed description of the two methods, see, e.g., Cooper and Slagmulder 1999, Götze and Linke 2008, Jahn and Krystek 2003).

In the following step, decomposed target costs have to be analysed to derive specific actions for target cost realisation (Götze and Linke 2008). Target cost analysis helps to cope with 
discrepancies between standard costs $^{2}$ and target costs (McNair et al. 2001). The evaluation process can be supported by calculating a target cost index and depicting results in a target cost value control chart. Both instruments facilitate the ascertainment of the target cost gap, and - most importantly - they give insights on where efforts should be concentrated. This enables a prioritisation of actions (Coenenberg et al. 1994; Götze and Linke 2008).

The overall objective of the target cost realisation step is to ensure that the standard costs of the final product are in line with the target costs while simultaneously meeting market requirements (Ax et al. 2008; Betz 1998; Fischer and Schmitz 1994). This objective is pursued by drawing on cost engineering techniques, most importantly value engineering (Park et al. 2016). ${ }^{3}$ As Figure 1 shows, this step partly overlaps the former ones, since target cost decomposition and target cost analysis occur throughout the course of product development, and insights of these steps are constantly fertilising each other (Martinez Ramos 2004; Monden and Hamada 1991). Ideally, the target cost realisation process leads not only to standard costs for the product being equal or below target costs so that the product can transcend into the market phase (Kee and Matherly 2006; Monden et al. 1997) but also to meeting determined target costing prices (Seidenschwarz 2003).

Monitoring and reporting in particular are important target cost control activities, which occur parallel to the target cost realisation to ensure that the whole product development process remains on track (Everaert et al. 2006). The extent to which standard costs deviate from target costs is calculated. The gained insights can be utilised to compare, evaluate and control the progress of target cost realisation (Coenenberg et al. 1994).

\subsection{Overview of criticism about target costing}

Target costing has received great appreciation because of its various advantageous traits that support a cost-efficient product development process (Jack and Jones 2008; McNair et al. 2001). Nonetheless, voices of concern have found a spectrum of limitations (for a preliminary overview, see Franz 1993), which can be classified as exogenous or endogenous (Kieser 2014). Whereas exogenous critique questions the fundamentals of a concept, endogenous critique accepts a concept's validity but notes particular methodological weaknesses.

\footnotetext{
${ }^{2}$ Standard costs are costs that would arise at a particular moment for the future product, given an organisation's current manufacturing capabilities, standards and cost structures (Flik et al. 1998; Krapp and Wotschofsky 2000; Kremin-Buch 2007). These costs are not fixed but can be influenced by cost management activities. Accordingly, the term standard costs is used to describe current costs that are determined at any point in time throughout the product development process for a future product.

${ }^{3}$ Cooper and Slagmulder (1999, p. 30) characterise value engineering as "a multidisciplinary approach to product design that maximizes customer value; it increases functionality and quality while reducing cost." Related to the understanding of early cost commitment, value engineering activities begin in parallel with the first stages of a product development process (Kato 1993). Here, the potentially high cost influencing capacity represents a great opportunity to align functionality and cost objectives (Newman and McKeller 1995). The intensity of value engineering activities should be particularly high before design drawings are fixed (Yasukata et al. 2013).
} 


\subsubsection{Exogenous criticism}

As exogenous critique questions the method's raison d'être, it is important to address these voices of concern first and elaborate on the necessity of target costing. To this end, we draw on the differentiation between decision-facilitating and decision-influencing as the two central purposes of management accounting systems in general (Demski and Feltham 1976) and hence of target costing in particular. Whereas decision-facilitating refers to the provision of the best possible information to help decision-makers meet organisational objectives, decision-influencing is concerned with providing necessary information to influence decisions in accordance to organisational objectives (Ewert and Wagenhofer 2014).

The exogenous critique in regard to target costing is essentially threefold. First, it is asked why specific target costs should be established. When looking at the different target cost calculation approaches, each approach bears limitations that contradict the determination of target costs, since problematic incentive effects appear to exist (Ewert 1997). For example, target costs derived through market-oriented calculation approaches are usually deemed as very challenging or even as unachievable (Cooper and Slagmulder 1999; Monden and Hamada 1991), and staff may conceive these target costs as arbitrary (Werner 2014). This, in turn, may negatively influence motivation and may lead to limited efforts (Cooper and Slagmulder 1999; Monden and Hamada 1991).

Concerning this critique, it can be argued from a decision-facilitating perspective that a target costing system can help managers conduct meaningful decisions. Ex ante, target costingrelated information can be used to evaluate the suitability of planned projects. Then, during product development, information about the target costing system is valuable for defining target costs as a standard against which to measure. This helps to identify if and where corrective actions are necessary. Finally, after product development, target costing information can be used to evaluate the development process and gain insights to improve upcoming projects.

The determination of target costs is also important from a decision-influencing viewpoint. With target costing, the objectives of people involved in the development process can be aligned to the ones of the organisation. Target costs constitute a point of reference to control whether development actions are in accordance to organisational requirements. The simple provision of target costs is also found to induce a proliferating work effort and value creation (Chwolka 2003). In short, the unspecific prompt of optimising the ratio of costs and functionality as good as possible is replaced by a clear objective for the staff involved.

Second, it is questioned why target costs should be reached at all. In this context, Chwolka (2003) stresses a possible discrepancy between target costs and break-even costs: the cardinal rule may prompt practitioners to refrain from introducing a product into the market be- 
cause it does not achieve its target costs, even if the break-even point for this product can be reached. This situation appears counterproductive, since the firm misses the possibility of generating profits.

From a decision-facilitating point of view, it can be responded that target costs represent long-term objectives of a firm that ensure strategic competitive advantage. In contrast, a positive break-even point rather mirrors a short-term advantage that can be realised. Target costing avoids this short-sightedness by focusing on the enduring prosperity of the company and sticking to the cardinal rule.

The requirement of reaching target costs is also relevant from a decision-influencing perspective. This can be substantiated by considering potential repercussions if staff is rewarded with introducing a product into the market that fails to achieve target costs. Allowing a product to transition to manufacturing without achieving its target costs negatively impacts target costing's behavioural control effects. A company would lose credibility and reputation amongst target costing team members for prospective target costing projects (Chwolka 2003).

The third issue pertains to the question of why cost optimisation efforts should cease when the target cost level is reached and why this point in time determines that the product can transition from its development phase into its market phase. Contrary to this characteristic of the target costing concept, it is argued that cost reductions - ceteris paribus - always benefit a company (Ewert and Ernst 1999). Accordingly, it seems inappropriate to stop cost-cutting efforts only because the target cost goal is achieved (Ewert and Wagenhofer 2014; Ossadnik 2009).

In the light of decision-facilitating, this criticism can be mitigated by arguing that the achievement of target costs is a confirmation to management that cost optimisation efforts are successful. A product can then be launched into the market with the substantiated confidence that organisational objectives will be met. Moreover, management receives information about when resources become available and can be directed towards other purposes.

From the perspective of decision-influencing, allowing cost optimisation efforts to cease if target costs are reached incentivises staff to sustain efforts until this goal is realised. This characteristic is valuable in the sense that there is a fixed scenario where efforts are rewarded, in terms of either monetary or non-monetary appreciation. Analogously, when considering potential negative repercussions for target cost non-achievement in whichever form, staff members should be sure when their efforts achieve a satisfactory level to avoid such repercussions. 
In summary, target costing can act as a valuable decision-facilitating and decision-influencing cost management system. Under this premise, target costing should not be disregarded per se, but its endogenous methodological deficiencies should be focused on.

\subsubsection{Endogenous criticism}

We identified six topics of endogenous criticism referring to methodological deficiencies of target costing. Figure 1 depicts these deficiencies and relates them to the traditional target costing process.

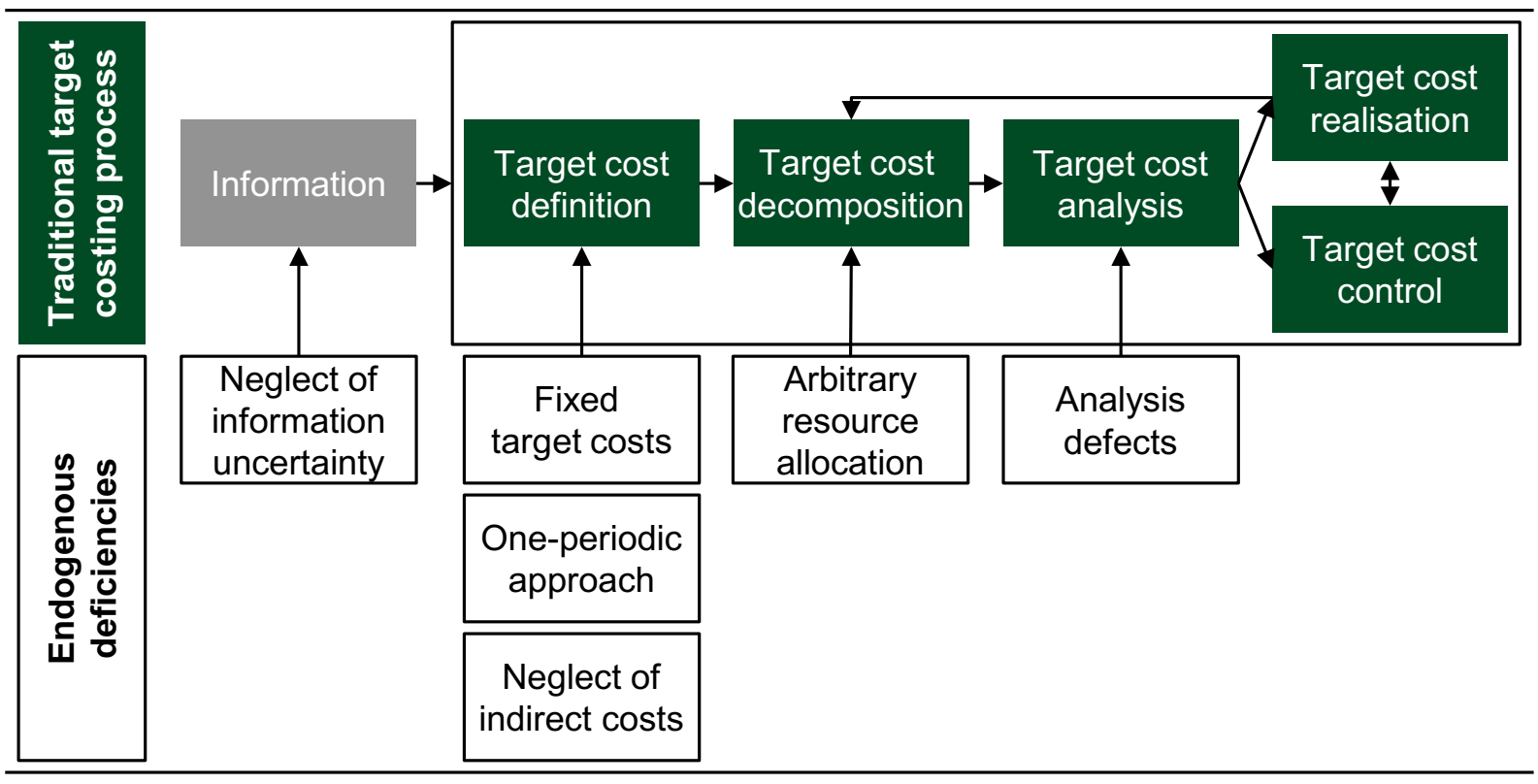

Figure 1: Endogenous methodological deficiencies of traditional target costing

From the inception onwards, detailed cost information forms the basis and runs through all of target costing's planning, realisation and control activities (Agndal and Nilsson 2009). The degree of accuracy of this information defines the quality for decision-making. Despite the centrality of accurate information, target costing's neglect of information uncertainty is emphasised as one critical but overlooked weakness (Dittmar 1996; Koonce et al. 2007). The particular relevance of the uncertainty problem is mainly due to the earliness of target costing's application during the product development process (Werner 2014), coupled with the necessity to look far ahead (Wouters et al. 2016).

Under the traditional approach, target costs for a product are subject to a one-time calculation, i.e., they are used as fixed target costs throughout the whole product development process. Each of the processed figures that make up target costs is, however, subject to changes in the course of time (Ewert and Wagenhofer 2014). In addition, the dynamics of relevant data along the time horizon cannot be taken into account in a static approach that is executed solely once (Götze 2010). This is unsatisfactory, because target costing is understood as an instrument to maximise product success throughout its life-time, which is confined by the neglect of dynamicity (Ossadnik 2009). 
The calculation model of traditional target costing reduces an actually multi-periodic decisionproblem to a one-periodic approach (Götze and Linke 2008; Ossadnik 2009). This is a strong simplification, since costs typically vary substantially throughout product development and the following phases of the product life-cycle (Bohrl and Listl 1999). The latter concept also highlights the fact that many markets have to address strategically relevant changes of sales quantities, selling prices and further factors, which are relevant for the determination of target costs. However, respective relationships between such factors are of little relevance in the traditional target costing model (Ewert 1997).

Although target costing is declared to be a full cost accounting approach, there is a strong tendency to neglect indirect costs in the phase of target cost definition (Bohrl and Listl 1999). "This partial cost accounting", as Bayou and Reinstein (2004, p. 167) stress, "is insufficient for product design projects where full costs are important". The problem becomes more and more relevant since the rate of indirect costs is steadily increasing in many organisations (Schmeisser and Bertram 2008). In particular, inefficiencies that may occur within indirect cost groups are likely to ruin the success of a product development (Dittmar 1996).

As mentioned, target cost decomposition can be based on the function-oriented method or the component allocation method. Both possess central weaknesses, leading to arbitrary resource allocation (Dittmar 1996; Götze and Linke 2008). The function-oriented method attempts to decompose costs by establishing a cost-benefit equivalency. However, the assumption of a linear relationship between target costs and customer requirements has been questioned (Coenenberg et al. 1994; Hoffjan 1994; Ossadnik 2009). Beyond this specific criticism, some authors generally challenge the connection of functionality and components: a cost-benefit ratio would be to some extent irrelevant for customers as long as their expectations are fulfilled (Ernst et al. 2009; Götze 2010; Weber and Schäffer 2014). The component allocation method allocates resources mainly according to prior products. Perpetuating historic cost structures and solution patterns may however be detrimental for future product success (Dittmar 1996). In the short run, there is the risk of allocating target costs without a connection to how much they are valued by the market (Dittmar 1996; Flik et al. 1998). In the long run, the method can impede innovative organisational activities and direct thinking towards old patterns of behaviour (Dittmar 1996; Kremin-Buch 2007).

Finally, analysis defects are addressed. Most obviously, the target cost index can systematically deliver distorted information (Brühl 2010; Kremin-Buch 2007). This pitfall stems from incorporating relative figures, which refer to different absolute bases. Further defects are assigned to the target cost value control chart. The respective critique is mainly concerned with the target cost zone. Its form is particularly advantageous for cheap and comparatively unimportant components. However, for achieving target costs, it is argued that every component should be of equal relevance. Additionally, target costing offers no specific guidance on 
how to objectively define the size of the target cost zone. This is problematic since the underlying subjectivity of defining the size of the zone significantly determines if components become relevant for cost management activities (Ernst et al. 2009).

\section{Further developments of traditional target costing}

\subsection{Research methodology}

To comprehensively identify the current state of the-art of target costing's methodological development, we have conducted a systematic review of the English and German literature, which we structured into three main steps (see Figure 2). These steps were based on a preliminary, rather undirected search within of all kinds of contributions, which helped us to increase our understanding about the topic at hand and most importantly to identify relevant keywords for our review. Searching for terms that are of a general kind to reflect the target costing literature as best as possible and avoid restrictions in the results, we finally determined three English and three German keywords. In addition, it was uncovered that the inception of English and German publications concerned with target costing can be dated back to 1988 .

\begin{tabular}{|c|c|c|c|c|}
\hline Step 1: & Languages & Keywords & Time span & Databases \\
\hline $\begin{array}{l}12,072 \\
\text { results }\end{array}$ & $\begin{array}{l}\text { English } \\
\text { German }\end{array}$ & $\begin{array}{l}\text { Target Cost } \\
\text { Target Costing } \\
\text { Total Cost Management } \\
\text { Zielkosten } \\
\text { Zielkostenrechnung } \\
\text { Zielkostenmanagement }\end{array}$ & $\begin{array}{c}1988 \\
\text { to } \\
2016\end{array}$ & $\begin{array}{l}\text { EBSCO HOST } \\
\text { ECONBIZ } \\
\text { Emerald Insight } \\
\text { GVK PLUS } \\
\text { JSTOR } \\
\text { SAGE Journals } \\
\text { ScienceDirect } \\
\text { Springer Link } \\
\text { Wiley Online Library } \\
\text { WISO }\end{array}$ \\
\hline Step 2: & Latest research & \multicolumn{2}{|c|}{ Quality assurance } & Analysis \\
\hline $\begin{array}{l}185 \\
\text { results }\end{array}$ & Journal articles & \multicolumn{2}{|c|}{$\begin{array}{l}\text { VHB-JOURQUAL } 3, \\
\text { rating } A+\text { to } C\end{array}$} & $\begin{array}{l}\text { Exclusion of duplicates } \\
\text { and non-relevant articles }\end{array}$ \\
\hline Step 3: & \multicolumn{4}{|c|}{ Focus } \\
\hline $\begin{array}{l}90 \\
\text { results }\end{array}$ & \multicolumn{4}{|c|}{$\begin{array}{l}\text { Contributions offering insights about further developments of traditional target } \\
\text { costing's methodology }\end{array}$} \\
\hline
\end{tabular}

Figure 2: Design of the state-of-the-art review

Based on the six keywords listed in Figure 2, the first step of the literature review comprised a comprehensive internet search. We examined ten online databases in the period from 
1988 to 2016 . In total, 12,072 potentially relevant publications were found. This huge number of sources made it necessary to use some filter criteria and conduct a second research step.

To identify high-level contributions, we concentrated on articles of journals listed in JOURQUAL 3. This is the journal quality ranking of the German Academic Association for Business Research. It separates non-scientific from scientific journals and categorises the latter based on their academic quality from $A+$ to $D$. Since the categories $A+$ to $C$ represent "outstanding", "leading", "important" or "acknowledged" journals, we concentrate our review on articles in journals of these categories. Less significance is subscribed to journals categorised as $D$, as they are viewed as implementation- or education-oriented journals. Since we focus on highly acknowledged methodological enhancements of target costing, we exclude journals of this category from our analysis. The remaining sources were scrutinised to exclude duplicate studies as well as non-relevant articles, i.e., articles that do not focus on target costing. As result, 185 potentially relevant journal articles remained. In a last step, we examined this portfolio of sources with regard to the question of whether the articles provide information about a further development of traditional target costing's methodology. 90 articles fulfilled this criterion. ${ }^{4}$

A detailed analysis of these remaining 90 articles made it possible to distinguish between three scopes of research to improve target costing, namely, the treatment of endogenous deficiencies, the extension of the planning horizon and the extension of the organisational scope. These scopes are illustrated in Figure 3 and will be discussed in detail in the following subsections.

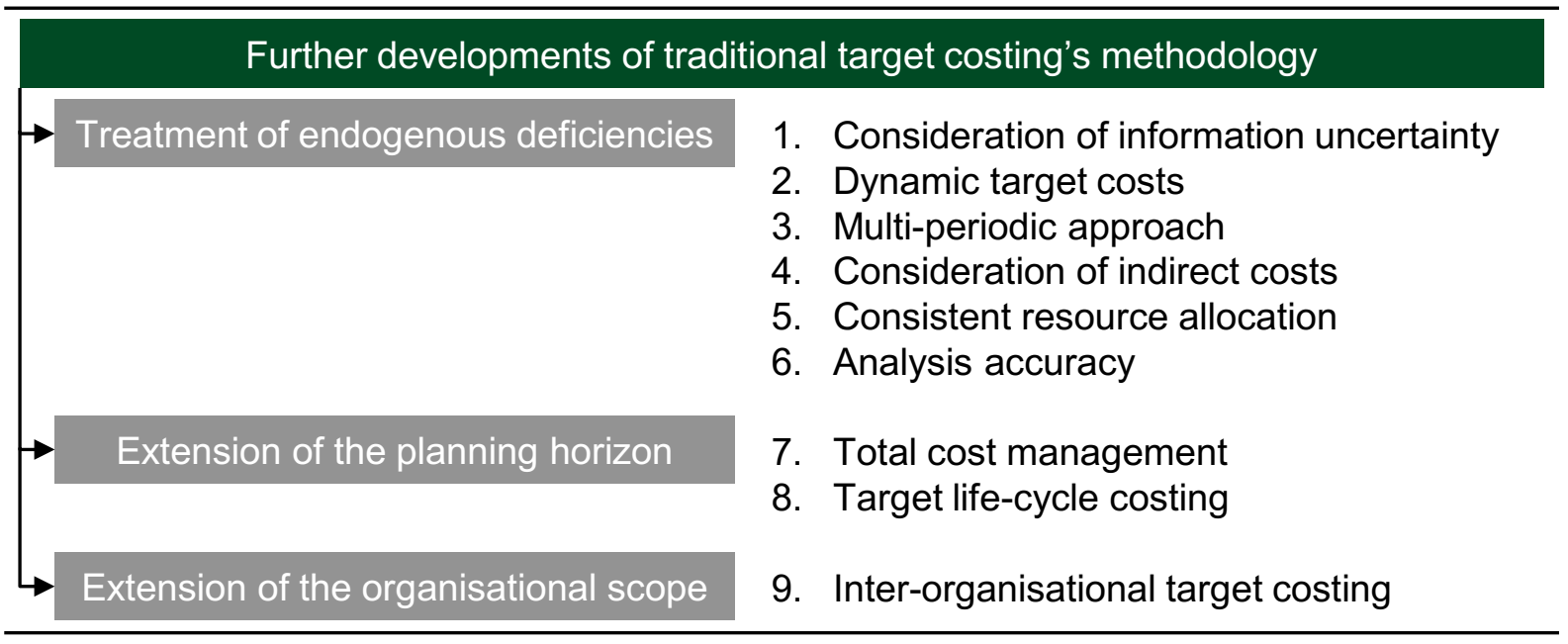

Figure 3: Further developments of traditional target costing's methodology

\footnotetext{
${ }^{4}$ In addition to this focus on methodological developments, there are other streams of research concerning target costing. For instance, Cinquini et al. (2015) as well as Yazdifar and Askarany (2012) explore target costing's diffusion in different companies or between countries. Other authors analyse changes necessary for adapting target costing to other industries, such as the assembly business (see, e.g., Everaert et al. 2006; Jack and Jones 2008), or in the context of the globalisation of companies and their supply chains (see Seidenschwarz 2008). Additionally, Cadez and Guilding (2008) as well as Chenhall (2003) examine factors that influence the application of target costing in companies.
} 


\subsection{Treatment of endogenous deficiencies}

As Figure 3 depicts, the enhancements of the target costing methodology proposed in the literature cover - with different emphasis - the six endogenous methodological deficiencies discussed in Section 2.2. The subsections below are structured accordingly.

\subsubsection{Consideration of information uncertainty}

To take information uncertainty into account, Götze and Linke (2008) call for more methodological support to better predict required product characteristics, sales quantities, sales prices and other key data. They propose devising a price-demand function to maximise prognosticated turnover or, for instance, utilising the so-called Conjoint+Cost approach (see Bauer et al. 1994). With this approach, simulations for different product and price configurations can be ascertained to identify the combination that yields a maximum profit.

Inbound target cost information possesses a subjective rather than objective character, because this information is mostly based on personal experience as well as estimates (Ehrlenspiel et al. 2014). In this context, Koonce et al. (2007) propose calibration analysis and risk analysis as ways of coping with information uncertainty. Calibration analysis is a technique to quantify estimation errors by contrasting computed and actual cost data. Variances in historic patterns can be spotted to amend estimates for the future product. Risk analysis enables companies to better quantify the effect of uncertainties, which in turn provides the basis for improved decision-making processes.

Target costing usually deterministically condenses the results of market analysis into aggregate figures. This approach, however, leads to inaccuracies and misinterpretations, because individual preferences are likely to diverge (Krapp and Wotschofsky 2000). To address this weakness, Krapp and Wotschofsky (2000) developed a concept that is based on stochastic variables to incorporate the uncertainty that results from diverting functionality expectations of customers. With this, the range of heterogeneous value requirements to realistically steer target cost realisation activities can be considered. The aim is then to decrease the standard deviation and increasing the probability distribution of the value to narrow the target corridor as far as possible.

Similar to this, Hoffjan (1994) suggests using fuzzy logic to address imprecise quantities. Nagasawa (1997) picked up this idea and proposes a route for advancement by drawing on fuzzy arithmetic to decrease the fuzziness involved in the cost and function evaluation. The uncertainty of target costing information can be highlighted by calculating a fuzzy quotient, i.e., the fuzzy ratio of functionality to costs. Activities then attempt to improve "the whole ordinal relation of the fuzzy quotient" (Nagasawa 1997, p. 566). 


\subsubsection{Dynamic target costs}

Regarding this topic, little methodological support for a continuous target costing model can be found in the literature. Solely Coenenberg et al. (1994) note that the validity of oncedefined cost objectives should be constantly re-assessed. This is only possible if target costing becomes responsive to changes and cyclic. However, the experiment of Gopalakrishnan et al. (2015) indicates that rather fixed cost goals motivate higher cost reduction performance of staff than figures that are prone to variability. Dynamic target costs may therefore increase the variability of cost figures and, if so, finally induce lower staff motivation.

\subsubsection{Multi-periodic approach}

To incorporate a multi-periodic view into target costing, different calculation schemes of dynamic capital budgeting are suggested (Mouck 2000). In particular, the net present value (NPV) and economic value added (EVA) have received attention in this context. To calculate the NPV, costs and revenues of traditional target costing have to be replaced by inward and outward payments. This leads to a modification of target costing's basic calculation model by amending its operands (Brühl 1996; Götze and Linke 2008). The advantage of this procedure is to explicitly consider capital costs and integrate the diverting occurrence of payments in time. Monetary interdependencies that arise for different periods can be considered. The insights gained from these relationships can be used to better guide target cost realisation activities (Brühl 1996). A problem experienced by using NPV in target costing to plan different construction projects was "a bias towards initial capital cost" (Nicolini et al. 2000, p. 313). The power of discounting cash flows was revealed as so strong that interdependencies of lowering quality to decrease early product costs in parallel to increasing later maintenance costs had little impact on the NPV (Nicolini et al. 2000). This particular insight is also valid in a more general sense. The more periods that are regarded and the higher the processed interest rates, the more likely an NPV model fosters biased decisions in favour of optimising initial capital costs, for example, by postponing payments.

In contrast to the NPV, EVA uses profits instead of cash flows to scrutinise a product's implication on organisational economic performance. For each period, the EVA can be computed to illustrate how much economic value a product creates or destroys. In order toTo assess the total value, the sum of all discounted EVA figures can be calculated. The decision of product implementation (cancelation) can then be based on a positive (negative) EVA (Kee 2010; Kee and Matherly 2006). It is known that the discounted value of the EVA of a product can be equivalent to its NPV. Then, by using EVA, the NPV of a product and the costs of capital can be ascertained without a modification of the operands of target costing.

A case study that analysed the integration of target costing and EVA by Woods et al. (2012) provided evidence for the subsequent pros and cons. Using EVA within target costing was 
demonstrated to change behaviour and broaden the attention of staff towards considering trade-offs from costs of capital. This led to an extension of potential cost reduction opportunities. Words of caution from the case indicate that extending target costing by EVA is not straightforward. The challenges of implementation especially relate to the extension of using EVA from a highly aggregated level to the product level. For this, concise and transparent information is required for EVA at a relatively detailed level.

\subsubsection{Consideration of indirect costs}

As an approach to increase the transparency of indirect costs and to effectively steer them, Götze (1993), Hoffjan (1994) as well as Schmeisser and Bertram (2008) suggest a combination of target costing with activity-based costing (ABC) (see Kaplan and Cooper 1998). Baykasoğlu and Kaplanoğlu (2007) developed a process-based service costing system that, amongst others, integrates target costing and $A B C$. Within a logistics company in Turkey, their instrument was used to identify and compare target costs and standard costs for activities. It was shown that a cost reduction gap within the indirect cost block can be discerned and, in conjunction with target costing, managed according to how much each activity provides value to the future product.

However, Bayou and Reinstein (2004) criticise that a combination of target costing and ABC does not naturally regard interactions between direct and indirect costs. Ignoring interdependencies among the costs of resources and activities weakens optimal product development. According to the authors, connecting $A B C$ with target costing - in contrast to simply implementing both methods in parallel - is the key to success. Only under this condition would a holistic evaluation of the implications of cost management activities on the relationship of direct costs and indirect costs be possible.

\subsubsection{Consistent resource allocation}

Towards a consistent resource allocation, Götze and Linke (2008) developed a theoretical model that expresses the dependency of the non-linear benefits from a customer's point of view and cost patterns in relation to the design of components. It focuses on direct product costs and attempts to mathematically allocate target costs on components while maximising customer satisfaction. Following the Kano model, the authors state that basic needs have to be fulfilled in any case, which is why they are not further considered in the model. Consequently, their model attempts to specifically maximise the ratio of customer satisfaction and component target cost allocation for performance needs and excitement needs by drawing on an additive value function. 


\subsubsection{Analysis accuracy}

With regard to the analysis defects of the target cost index, Brühl (2010) developed two solutions. The first alternative applies the whole target costs not only as a denominator to calculate a component's percentage of target costs but also to calculate the component's percentage of standard costs. With this common basis, the resulting modified target cost index prompts adequate actions. The second alternative to counter analysis defects draws on the advantage of ratios that are based on absolute costs rather than percentages. A component's target cost index results then when respective absolute target costs and absolute standards costs are contrasted.

As shown by Brühl, both calculation schemas lead to the same results, i.e., to identical index values that induce adequate actions. This may be further illustrated by sketching the data into a target cost value control chart to graphically depict the relative cost situation of product components (or parts, respectively). With this, decision-making is enhanced by providing reasonable information that initiates practitioners to take the right measures.

3.3. Extension of the planning horizon

Apart from improving traditional target costing with regard to already criticised methodological deficiencies, the concept has been further developed in terms of extending the planning horizon it currently encompasses. The resulting advancements come under the heading of either total cost management or target life-cycle costing.

\subsubsection{Total cost management}

Production commencement indicates the endpoint of the traditional target costing process (Gagne and Discenza 1995). Scientists, however, stress the necessity to extend target costing towards a holistic cost management approach. Total cost management (TCM) is such an approach, which acts as an umbrella term of cost management activities that prevail during product development and production processes alike. It combines target costing and kaizen costing as an all-encompassing concept of on-going cost management (Monden 1993; Monden and Hamada 1991).

Kaizen costing substitutes the market perspective of target costing by stressing an internal focus. Concerned with optimising production processes (Cooper 1996; Shank and Fisher 1999), it contributes to persistent cost reduction during the market phase of already-existing products (Modarress et al. 2005; Sénéchal and Tahon 1998). Therefore, kaizen costing possesses comparatively less leeway for cost optimisation, since its efforts address products whose functionality is already defined and cannot be changed easily. Based on the resulting limited influence on product design, it is stated that kaizen costing activities may influence only approximately $10 \%$ of a product's costs, in contrast to approximately $90 \%$ within target 
costing (Cooper 1996). It is therefore of little surprise that Monden and Hamada (1991, p. 17) described the meaning of the word kaizen as "continuous accumulations of small betterment activities rather than innovative improvement."

Finding opportunities for cost efficiency principally requires the involvement of everyone throughout the corporation (Afonso et al. 2008; Monden and Hamada 1991). Consequently, both target costing as well as kaizen costing are team-based approaches that integrate staff from various functional departments (Baykasoğlu and Kaplanoğlu 2007). Kaizen costing's optimisation activities during the market phase are methodologically supported by value analysis, which is the equivalent to value engineering applied by target costing during the product development phase (Götze 1993; Modarress et al. 2005).

Two main fields of application for kaizen costing can be distinguished. First, the concept is used as a means for steady cost optimisation to maintain a competitive advantage. Second, it is applied when a product is introduced into the market for strategic reasons, i.e., although its standard costs were above its target costs; then, kaizen costing is supposed to reduce standard costs towards the level of target costs (Agndal and Nilsson 2008; Baykasoğlu and Kaplanoğlu 2007; Götze 1993).

In summary, TCM acknowledges that cost optimisation is an on-going process, even once the product transitions from the development phase into the market phase. The combination of target costing and kaizen costing is therefore a logical conclusion rather than an artificial construct. Although few voices of concern regarding TCM were found, it can be inferred that interfaces and interdependencies develop. They must be managed carefully, especially when taking into account that TCM can be recurring, which means that kaizen costing becomes an input of target costing.

\subsubsection{Target life-cycle costing}

Some authors subscribe a life-cycle perspective ${ }^{5}$ to traditional target costing (see, e.g., Kato 1993; Nicolini et al. 2000), although it does not particularly consider interdependencies of costs arising at different life-cycle phases. As a typical example for such an interdependency, take a company that chooses to decrease product quality to achieve target costs. This may lead to cost savings during the market phase but may increase warranty costs in the postsale phase. The target life-cycle costing (TLCC) approach addresses such issues.

TLCC can be characterised as a proactive and holistic cost management system that encompasses all product life-cycle phases. Accordingly, not only manufacturing costs but also, e.g., costs of maintenance, recycle and disposal that occur during the post-sale phase are part of the figures incorporated within target cost calculation. This extended target costing

\footnotetext{
${ }^{5}$ We follow Atkinson et al.'s (2012) distinction here. As such, a product's life-cycle consists of three phases: (1) development phase, (2) market phase and (3) post-sale phase.
} 
system stresses trade-off effects and decision interdependencies (Coenenberg et al. 1994). As stakeholders become more conscious of environmental issues today, a proliferating emphasis on ecological themes and regulative pressures further underscores the importance of TLCC. In this context, TLCC is also characterised as facilitating sustainable competitive advantages (Nishimura 2014).

Jander et al. (2006) developed a TLCC approach that considers the effect of product qualityinfluencing development activities on warranty costs for BMW motorcycles. TLCC was evaluated as a valuable means to stop purely concentrating on the costs of product development and direct cost management activities by consistently regarding cost implications and interdependencies throughout all product life-cycle phases. Exceeding the defined level of target costs in the development phase to increase product quality can now be accepted, if this surplus is accompanied by savings during the market or post-sale phase (Jander et al. 2006).

As can be discerned, TLCC entails a new challenge for cost optimisation (Nishimura 2014). For instance, this sustainability-oriented dimension needs to be integrated into and balanced with target costing activities. Therefore, target cost realisation activities are becoming a more complex exercise (Nicolini et al. 2000). The necessity arises to extend the target costing model to incorporate and evaluate multiple objectives to support multi-criteria decisionmaking processes. Furthermore, Nicolini et al. (2000) found additional potential obstacles for the success of TLCC in their case study of the UK construction industry, namely, the difficulty and complexity of reliably estimating and prognosticating data of service life, durability and maintenance. In line with that, the authors characterise TLCC as a straightforward notion that is challenged by the availability of proper models and dependable information.

Lastly, it seems not far-fetched to devise a TLCC model that is grounded in investment theory. Diverting implications of product design alternatives on different product life-cycle phases can appropriately be portrayed with this. Similar to the already presented descriptions of integrating the NPV method into target costing, inward and outward payments of all live-cycle phases have to be predicted as a prerequisite to comprehensively improve product success (Brühl 1996). However, TLCC then has to address the same problems as the multi-periodic approach illustrated above.

\subsection{Extension of organisational scope}

With the rise of the supply chain management literature, it is postulated that a company maintains its competitiveness only by steadily improving the efficiency of the whole supply chain, in contrast to solely its own performance (Cooper and Yoshikawa 1994; Kulmala et al. 2002). Following this understanding, companies assume an outward focus to maximise their competitive advantage by optimising inter-organisational cost structures (Cooper 1996). In 
line with this, cost management activities have developed into so-called inter-organisational cost management (IOCM) (Cooper and Slagmulder 2004).

Many consider inter-organisational target costing (IOTC) as the most central instrument for IOCM (see, e.g., Agndal and Nilsson 2009; Axelsson et al. 2002; Cooper and Slagmulder 2004). In contrast to receiving an offer for goods to be purchased, IOTC determines that a buyer pre-calculates his feasible costs for goods and communicates them to his suppliers. With this proactive procedure, a buyer's ability to manage and reduce costs increases (Newman and McKeller 1995). In addition, the approach is valued as benefitting supplying companies and increasingly satisfying customer demands (Ellram 1996; Jack and Jones 2008). Accordingly, Ellram (1996, p. 16) categorises IOTC as an analytical tool that "focus[es] on continuous improvement of both the buyer's and the supplier's processes in order to achieve a high-quality output at the best total cost." Furthermore, IOTC is characterised as particularly transmitting market pressure to suppliers (Agndal and Nilsson 2009; Axelsson et al. 2002), building buyer-supplier relationships (Varoutsa and Scapens 2015; Windolph and Moeller 2012) and controlling inter-organisational product development (Axelsson et al. 2002; Martinez Ramos 2004). Open book accounting is a possibility to support the potentially farreaching cooperation initiated by IOTC (Wouters and Morales 2014; Wouters et al. 2016).

However, the advantageousness of IOTC is contested. Instead of integrating network partners to work towards a joint objective, buyers may use IOTC to simply pass market pressure to suppliers and remain profitable for their own sake (Seal et al. 2004). According to Cooper and Slagmulder (2004, p. 6), this makes IOTC "an arm's-length cost management technique". Empirical evidence substantiates this notion, revealing that suppliers rarely become involved in the buyer's target costing team. In fact, target costs are cascaded down and handed on to suppliers (Kocsoy et al. 2009; Lamming 2000). Mclvor (2001) even witnessed an electronics manufacturer who exploited its superior position in the chain by using cost information to erode supplier margins. Similarly, Varoutsa and Scapens $(2015$, p. 77$)$ revealed in a case study that "target costing was imposed on suppliers in a quite aggressive way."

Another point of criticism emphasises the realisation of IOTC as a challenging sociotechnical process. Not only the technical implementation but also the alignment of human resources and capabilities need to be mastered (Bastl et al. 2010). Similarly, it is difficult to realistically quantify target costs in the beginning of the development process. At this time, product blueprints are still in their infancy, which makes it almost impossible to pass reliable cost figures to suppliers (Agndal and Nilsson 2009). For instance, Mouritsen et al. (2001) report in their case study that an electronics manufacturer found it difficult to set target costs to suppliers because of the significant degree of technological changes in the respective industry. Tight cost control, through setting precise target costs to suppliers, is therefore not practicable, since it may confine the innovativeness of suppliers. 


\subsection{Synopsis}

The large extent to which target costing has been qualitatively and quantitatively extended provides evidence for the unrestrained relevance of this cost management system. Our literature review revealed that traditional target costing has been developed further in multiple directions. Table 1 gives a summary of these attempts, but it also draws a picture about research to be done in the future. In addition, the table highlights relevant sources that have formerly been cited in relation to each route of further development.

$$
<<\text { Insert Table } 1 \text { here }>>
$$

It is obvious that researchers have already offered a broad spectrum of possibilities for improving traditional target costing. At the same time, the table highlights a number of remaining tasks to further enhance target costing methodologically. The challenge here is to set priorities and focus on those topics, which are particularly beneficial not only from an academic point of view but also for practice. This dual perspective seems imperative, as simplicity is one of the strengths of target costing, which fosters its acceptance and implementation in companies. In contrast, some of the further developments of traditional target costing appear rather sophisticated, in comparison to the benefits they may provide. For instance, despite the potential value of fuzzy arithmetic from a methodological point of view, its application in target costing teams needs a higher level of cognitive capabilities amongst team members. Therefore, its implementation may be hindered due to confined practicability and comprehensibility. A second example is the proposition to devise a dynamic target costing model to ensure a constant alignment of target costs to progressing circumstances. This incorporation of uncertainty can affect target costing's decision-influencing function, since - in contrast to specific goals - vague goals consistently fail to arouse maximum effort (Locke and Latham 2002).

In this respect, also Kajüter's (2005) findings are of relevance. He analysed target costing, $A B C$, benchmarking and life-cycle-costing individually as well as combinations of these instruments from an empirical point of view. Among other things, he found a reduction of effectiveness when too many instruments are combined. Therefore, fostering research concerning the effective combination of different cost management tools could be fruitful.

\section{Prospective advancements for target costing}

\subsection{Research methodology}

The multiplicity of potential enhancements of target costing provides the opportunity to try to identify those research areas that are and will be of high relevance to theory and practice. It accordingly appears necessary to apply some filter criteria. Therefore, we expand the scope 
towards identifying pressuring needs of companies at present as well as especially towards the current and upcoming developments in the field of management accounting. We draw attention towards future themes of management accounting and use the gained insights to identify upcoming research areas for target costing. Based on this, it will be scrutinised to what extent potential and prospective research areas of target costing intersect to distinguish between themes of lower relevancy and themes of higher relevancy to methodologically advance target costing.

Two large-scale empirical studies on the future themes of management accounting were recently conducted by Schäffer and Weber $(2012,2015)$. Grounded in 448 and 472 answers in 2011 and 2014, respectively, from executive managers of German, Austrian and Swiss companies, both studies together identified the twelve topics listed in Table 2. As these topics have the potential to influence the profession of management accounting, they also influence and challenge target costing. Hence, they can serve as a framework to analyse to what extent target costing needs to be developed to cope with the future requirements.

Significant influence for target costing

Behavioural management accounting

Cash-orientation

Information systems

Involvement in strategic planning

Sustainability

Volatility
Subordinate influence for target costing Business partner Compliance Demands to management accountants Internal and external accounting Internal communication Management accounting's efficiency

Table 2: Future themes of management accounting and their influence on target costing It is apparent that the future themes of management accounting are of different relevance for target costing. We identified the six topics listed in the right column of Table 2 as being of minor importance, because solely a weak direct relationship between them and target costing exists. The other six topics exert a significant influence on target costing in this sense that they touch the core of target costing's current methodological status quo and direct its future routs for advancement. Therefore, we explore these six topics more deeply in the following.

\subsection{Behavioural management accounting}

In response to the homo oeconomicus paradigm, Simon (1972) introduced the notion of "bounded rationality" to account for the restricted processing capacity of the human brain and the resulting limitations in judgement and decision-making. Transferring Simon's concept to the area of accounting leads to the research stream of behavioural management accounting, which focuses on how people actually decide and take actions based on accounting information. Although many accounting instruments have been investigated already in light of 
behavioural issues, target costing might also be a fruitful topic for respective research. Issues such as mistakes in one's reasoning (Gehrig and Breu 2013), motivational deficits (Küpper et al. 2013; Wagenhofer 1997) and inadequacies of information processing capabilities (Becker et al. 2014; ICV 2013) are likely to arise in the target costing context, as well. These issues might have a considerable influence on decision-making processes during target costing.

In line with behavioural management accounting research assuming either a descriptive or a prescriptive perspective (Taschner 2015), upcoming target costing studies could take both views. On the one hand, descriptive research should attempt to discern central factors of bounded rationality that impede the value of target costing for proper decision-influencing. It seems necessary to investigate the influence of target costing information on goal-oriented behaviour of individuals and teams, which are characterised by cognitive limitations. The specificity of this research stream can be enhanced by differentiating between cognitive limitations with regard to various factors that can be ascribed to mistakes in one's reasoning, motivational deficits and inadequacies of information processing capabilities.

On the other hand, from a prescriptive point of view, the question arises of how target costing needs to be designed to unfold its decision-influencing function best. With regard to motivational deficits, research that addresses this issue should be based on a thorough theoretical foundation, for example by drawing on the goal setting theory of motivation (Locke 1968). Insights of Everaert and Bruggeman (2002) as well as Monden et al. (1997) could be used as a starting point. The latter, for instance, revealed a positive relationship of staff participation in goal setting and their cost reduction performance. The findings further substantiate that individual performance evaluation, which is understood as staff being evaluated only on information they can control, increases the motivation to achieve target costs.

From a goal-oriented perspective, performance is influenced by the suitability of goals. As such, goals can have various characteristics with positive and negative implications on behaviour and therefore goal achievement (Locke 1968; Locke and Latham 2002). For target costing, the consideration of and adaptation to these implications become obligatory. This cost management system seeks to determine objectives that initiate goal-congruent efforts of the target costing team. To ensure this, it is important to scrutinise which characteristics target costs should possess and to tailor them correspondingly.

To conduct behavioural-oriented target costing research, different research designs appear applicable. In addition to an analytical approach, various types of empirical research can be applied (Wouters et al. 2016). Experiments, as one such type, appear especially fruitful, because they enable data generation within a controlled environment. The ascertainment of hypotheses and analysis of real human behaviour in specified conditions become possible. 
Respective findings can then be taken into account in the context of methodological developments of target costing.

\subsection{Cash orientation}

Cash management is an area of financial management with the aim of achieving an optimal level of liquidity (Vilain 2006). By assuming a cash orientation, organisations attempt to improve their financial agility and flexibility to sustain a competitive advantage and cope with volatility. Therefore, managing the temporal offset between inward and outward payments is a significant aspect of cash management (Staroßom 2013).

In consideration of the necessity to ensure liquidity, incorporating cash-oriented thinking into target costing activities appears beneficial. Since prior developments already extended target costing to a multi-periodic approach that is based on inward and outward payments, the first step is already made (see, e.g., Götze and Linke 2008; Kee 2010; Kee and Matherly 2006). For additional research in cash-oriented target costing, different possibilities seem to be meaningful, most suitably addressed through theoretical and conceptual research designs. For example, cash orientation is mainly mirrored through aligning efforts with aspects of working capital management. This, amongst others, seems to be of particular importance to target costing when the object of consideration is not an isolated product but a portfolio of products. While current developments of target costing that are based on payments can be used to determine the present value of a product, the complexity of interdependencies in a multi-product setting is not directly captured. Since many facets determine this complexity, great room for theoretical advancement and conceptual reinterpretation as well as progress of current practices exists. For instance, the interrelationship of payments among disparate product development projects affects the overall (un)availability of funds and organisational returns as well as credit worthiness.

Wouters and Morales (2014) as well as Wouters et al. (2016) generally criticise target costing's oftentimes limited scope in terms of not considering that a particular development project may be highly impacted by choices made in other product development projects. With regard to working capital management, each product can, on the one hand, have a positive present value. On the other hand, the working capital consumed by all product developments may in sum impede organisational liquidity to an extent that puts that entity in danger. This issue should be taken into account from the perspective of a multi-product target costing that is aligned with the working capital approach.

\subsection{Information systems}

The potential benefit of information systems on target costing is significant and manifold, as they can facilitate transparency and reduce complexity within the target costing process $(\mathrm{He}-$ vner et al. 2004; Stair and Reynolds 2016). Apart from some tentative notions (see, e.g., 
Kato 1993; Mouritsen et al. 2001; Nicolini et al. 2000), however, little research on information systems in the realm of target costing has been conducted. For instance, aspects of how and where information systems can be used to increase the effectiveness and efficiency of target costing have not been explored in detail. Since a stream of information systems research focuses particularly on antecedents and determinants that define information systems success (see, e.g., DeLone and McLean 1992; Petter et al. 2013), these insights may also be used as a point of reference and be evaluated in the context of target costing. Next, the repercussions of information systems on information uncertainty should be evaluated.

The increasing demand of coping with different variations of one product (Yalcinkaya et al. 2017) has created a new research field. From an operational point of view, practicability issues confine the current application of target costing. It is typically used to steer a defined basic product, irrespective of the product's degree of modification. A spectrum of variations of a product is often not regarded (Kremin-Buch 2007). However, by not considering the breadth of product modifications, target costing's support for proper decision-making is limited. It is conceivable that even though a basic product model achieves its target costs, the product's modifications exceed the expected target cost level. In this case, a product may overall be unprofitable. Research on information systems that process data about product modifications seems therefore fruitful for enhancing the quality of target costing decisionmaking.

In respect of disparate data sources from organisational functions, interoperability is a further challenge for information management (El Kadiri et al. 2016). It is already a challenge to exchange internal information from different organisational functions, which oftentimes use heterogeneous information systems and to distribute this information in a manner where users receive only the information relevant for them. In an inter-organisational setting, this complexity multiplies. As target costing activities are based on cross-functional - and possibly also inter-organisational - cooperation, target costing information systems must be capable of dealing with the described complexity. Here, further research is necessary to address the increasing challenges of analysing, integrating and sharing target cost information intra- and inter-organisationally.

Because information systems tend to be tailored to specific organisational circumstances and requirements, empirical research in terms of observations and surveys, particularly in the form of case studies, might generate insightful initial findings. While research should not be restricted to case studies, which inhibit causal interference and generalisations to broader settings, they are effective for uncovering research problems, generating hypothesis pertaining to novel relationships in distinct contextual settings and, at least, indicating routs for potential generalisations (Chenhall 2003). Therefore, in a first step, case studies could provide insights about what occurs if traditional target costing is applied in the context of a product 
with different variants and additionally in an inter-organisational context. Then, the actual information demand can be evaluated so that a requirement-specific information system can be designed in the next step.

\subsection{Involvement in strategic planning}

Strategic planning broadly consists of a strategy development phase and an implementation phase. Currently, management accountants usually act within the latter. However, since both areas together support organisational success, management accountants and strategists start to converge. This leads to an extension of the scope of management accountants as they start to engage within strategic development (Weber et al. 2012).

For target costing, this future theme is of significant relevance, because target costing processes are typically strategic. ${ }^{6}$ Overall, strategic planning can further reduce information uncertainty for target costing. Studies that identify how and which aspects of strategic planning are integrated into target costing are still in their infancy, though. Preliminary notions exist that stress the definition of corporate long-term sales and profit objectives as well as the structuring of product lines as strategic corporate planning activities, which influence product level target costing (Cooper and Slagmulder 1999; Götze 1993; Monden and Hamada 1991). These aspects have to be incorporated into a specific new product development project so that corporate strategic planning and target costing activities can be aligned with each other (Monden and Hamada 1991). As a starting point, theoretical and conceptual research designs concerned with proposing well-structured ideas for such an integrative framework may be a suitable path for this. Then, the developed frameworks can be applied in real-world companies and evaluated by users in form of structured interviews or surveys.

However, research intentions should not cease once aspects of strategic planning are integrated into target costing. Strategic planning is an on-going and cyclic process, with strategic plans being constantly validated for suitability and, if necessary, amended according to current conditions. In the case of changing variables of strategic planning, target costing activities may need to be realigned as well. However, the question of how the alignment of strategic planning and target costing is constantly ensured is a topic rarely addressed so far.

Voices of concern in respect of the effect of strategic planning on product development projects may be evaluated in the context of target costing. For example, Song et al. (2011) found empirical support for the contention that formal strategic planning decreases the amount of new product development projects, because it limits the creation of project ideas. As a possible solution to remedy this negative effect of formal planning on behaviour, the authors propose allowing improvisation by developing flexible strategic plans. Additional

\footnotetext{
${ }^{6}$ For a discussion of possibilities of target costing for start-ups in regard to a lean start-up management, see Seidenschwarz (2015).
} 
studies that ascertain to what extent target costing should be detached from strategic planning are accordingly needed to shed light onto when strategic planning limits innovationrelated target costing activities. It can be inferred that this research has do address the dichotomous relationship of strategic planning and target costing. In contrast to the negative tone of Song et al. (2011), it is conceivable that formal strategic planning acts as a quality filter for upcoming project ideas. This may lead to a decreasing amount of ideas but may simultaneously increase the quality of the product selection process.

\subsection{Sustainability}

The concept of sustainability calls for various routs of advancement from a management accounting point of view (Schaltegger and Burritt 2010; Weber et al. 2012). Up to now, however, comprehensive sustainability notions have had little impact on advancing target costing methodologically. A starting point for sustainability-centred target costing research lies within the concept of TLCC (see, e.g., Jander et al. 2006; Nishimura 2014). Although it does not highlight a multi-dimensional perspective in the sense of balancing economic, ecological and social factors, this concept is valuable for avoiding short-sighted decision-making, since interdependencies of decisions regarding the whole life-cycle of a product are considered.

The next step should be to thoroughly integrate all dimensions of which sustainability consists in TLCC. Then, diverse routs for further research unfold. For instance, important revelations can be expected if research attempts to unveil interfaces of target costing and sustainability. It is essential to investigate which sustainability aspects are of considerable relevance for target costing (Maas et al. 2016). As an example for such points of intersection, target costing and sustainability accounting both focus on product materials (Cooper and Slagmulder 1997; Götze and Linke 2008; Maas et al. 2016).

However, harmonising the diverse views of the three dimensions of sustainability is already a challenging objective (Michel 2011; Schaltegger and Burritt 2010). Additionally, the measurement of environmental and social aspects is generally characterised as a difficult endeavour (Schäffer 2016). Both problems become even more complex in relation to target costing. It can be expected that companies require new sorts of high-quality, forward-looking and non-financial information to conduct sustainability-oriented target costing. Not only economic but also ecological and social aspects have to be made transparent (Michel 2011; Schaltegger and Burritt 2010). An innovative target costing concept that is capable of identifying, recording and monitoring this kind of data is needed.

As supply chain management notions become increasingly relevant for sustainabilityoriented concepts in general and target costing in particular, further research is necessary. Extending sustainability-centred target costing to include upstream and downstream entities of a supply chain appears to be a highly complex task. Firstly, economic, ecological and so- 
cial aspects that are relevant to target costing within a supply chain are difficult to grasp. Secondly, activities of each supply chain partner affect sustainability differently, so sustainability-related information is dispersed within the whole supply chain and partners need to cooperatively work together. The last factor includes the willingness of every company involved to create an overall win-win situation and fairly share gained benefits (Burritt and Schaltegger 2014). Future studies should hence explore how each supply chain entity can contribute to sustainable IOTC and how these individual contributions can be measured and fairly distributed. Methods to quantify impacts and trade-offs among the three dimensions within a supply chain have to be designed and implemented.

In light of the sketched research directions, initial sustainability-oriented target costing may essentially draw on empirical research. Again, surveys and case studies seem to be of high relevance. They can generate, on the one hand, in-depth insights from individual organisations. On the other hand, information and data could be used for the purpose of crossorganisational comparisons. This latter kind of empirical research can help to establish best practices and to derive measures for improvement. However, since data on sustainability factors can rarely be measured monetarily, it has to be investigated the extent to which concepts of generating best practices can be fruitful in this context. For instance, Data Envelopment Analysis is a tool that seems to be of high interest, as it has already been used many times in the sustainability context (Zhou et al. 2018). Other approaches that may be considered are, e.g., Stochastic Frontier Analysis, TOPSIS and OCRA.

\subsection{Volatility}

Volatility is a construct that measures the frequency, intensity and unpredictability of variations within a specific time frame (Schäffer et al. 2014b). It indicates dynamicity and risk (Weber et al. 2012). Dealing with volatile environments is one of the greatest challenges for management accountants (Horváth 2012; Schäffer and Botta 2012). Volatility has a specific connection to target costing in regard to information uncertainty, long-term planning as well as development horizons and dynamic markets.

The general concept of volatility has been characterised as an "elusive construct" (Dugal and Gopalakrishnan 2000, p. 402). This starts with the use of terms such as turbulence, dynamism and discontinuity interchangeably for volatility. Furthermore, the phenomenon is studied from different angels, for example, a financial, organisational or environmental perspective, from which the construct of volatility is interpreted differently. Therefore, scientists should first precisely conceptualise volatility in relation to target costing to achieve research homogeneity and solid theory advancement (Dugal and Gopalakrishnan 2000).

With this foundation, it should be investigated which dimensions of volatility affect target costing. Insights can be derived from wide-spread current research that focuses on volatility and 
related constructs. For instance, it has been extensively studied to what extent volatility dimensions such as technological turbulence, market turbulence and competitive intensity affect organisational performance (Andotra and Gupta 2016; Heirati et al. 2016; Hung and Chou 2013). A fruitful path could be to utilise theoretical research designs to evaluate and discuss the respective findings in the light of target costing. This kind of research could be used to formulate hypotheses for upcoming empirical analyses.

To optimally steer product development activities, efforts to manage the degree of uncertainty that results from volatility are required. This opens numerous research avenues, since risk management mechanisms can be applied to cope with implications from different volatility dimensions (van Rensburg and Pretorius 2014). For instance, volatility-centred target costing research should scrutinise how risk or uncertainty that results from volatility can be anticipated and managed in the target costing process. Methods that are capable of responding to the induced risk or uncertainty are required.

An empirical survey revealed that organisations particularly utilise management accounting instruments, such as forecast instruments, planning instruments, risk cockpits, hedging and scenario as well as sensitivity analysis, to address proliferating volatile environments (Schäffer et al. 2014a). A holistic consideration of risks, the evaluation of scenarios as well as alternatives, and the utilisation of sensitivity analyses or simulations help to bypass mental barriers and enable fast actions in case of occurring changes. However, it seems to be difficult to analyse the influence of these divergent instruments when handling information uncertainty empirically. Therefore, a simulation could be the research method of choice. Simulations allow researchers to model different scenarios. In particular, potentially relevant factors influencing the performance of each method can be regarded separately.

In addition to handling uncertainty within processed information to adequately determine target costs at the beginning of the product development process, volatility exerts a constant influence on target costing. The intensity or relevance of once-considered volatility dimensions can change throughout the product development process. It can therefore again be discerned that the development of a dynamic target costing model could be advantageous. Through a constant re-assessment, target costing provides support to ensure the achievement of satisfactory results.

\section{Conclusion}

Although target costing is an extensively studied topic, a holistic investigation into its methodological developments is missing. The paper seeks to fill this gap, revealing that research in this context is far from reaching maturity. Based on a systematic literature review, our state-of-the-art analysis of 90 articles in highly rated journals emphasised nine distinct re- 
search streams that pursue the further development of traditional target costing. We grouped these streams into three research scopes (the treatment of endogenous deficiencies, the extension of the planning horizon and the extension of the organisational scope) and outlined the respective achieved progress as well as remaining tasks to further enhance target costing methodologically.

Due to the abundance of potential research areas determined, the results of two large-scale empirical studies were used as a filter. In these studies, Schäffer and Weber $(2012,2015)$ identified twelve future themes of management accounting. We characterised six of them as being particularly influential to target costing. Accordingly, we aligned them with five key topics to advance target costing, namely, (1) consideration of information uncertainty, (2) dynamic target costs, (3) multi-periodic approach, (4) TLCC and (5) IOTC. Figure 4 illustrates this alignment and the resulting research agenda, which - while some indications about applicable research designs have already been proposed - may be addressed through empirical and non-empirical research alike.

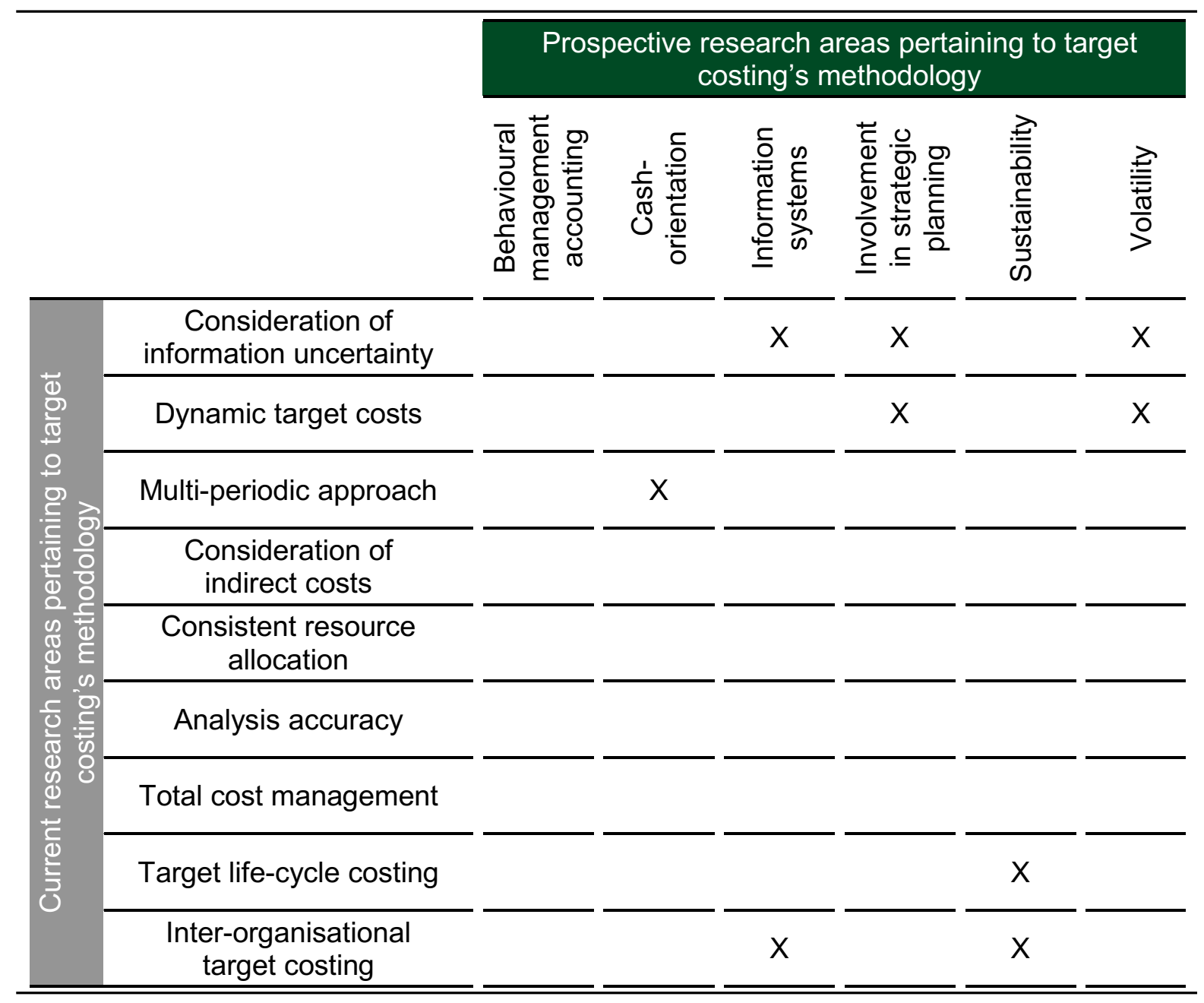

Figure 4: Highly prospective research directions for target costing's methodological development 
As with every other study, our work has some limitations. With regard to the state-of-the-art analysis, the search algorithm for the systematic literature review possibly did not identify all relevant journal articles. In addition, by deciding to scrutinise high-quality journal articles only, the sample deemed as important is naturally confined. Furthermore, we did not analyse the extent to which the sources cited by the journal articles provide additional knowledge for the state-of-the-art.

The utilisation of the two studies of future themes of management accounting may also be criticised due to its confined scope. Although the two studies together can be characterised as large scale, generalisations derived from these findings should be regarded with caution. As respondents of both studies were solely from Germany, Austria and Swiss, this further confines the general validity of the identified topics.

To mention lastly, it was chosen to concentrate on a subset of the twelve future themes of management accounting. Hence, the discussed implications for future research on target costing are not encompassing but rather selective. With this qualification, our paper

- reveals to managers of which issues they should be particularly aware because they are likely to affect the effectiveness and efficiency of their target costing processes, and

- can help researchers select between alternative routes to further develop target costing and to more easily find promising upcoming research topics.

\section{Literature}

Afonso P, Nunes M, Paisana A, Braga A (2008) The influence of time-to-market and target costing in the new product development success. International Journal of Production Economics 115(2):559-568.

Agndal H, Nilsson U (2008) Supply chain decision-making supported by an open books policy. International Journal of Production Economics 116(1):154-167.

Agndal H, Nilsson $U$ (2009) Interorganizational cost management in the exchange process. Management Accounting Research 20(2):85-101.

Albright T, Lam M (2006) Managerial accounting and continuous improvement initiatives: A retrospective and framework. Journal of Managerial Issues 18(2):157-174.

Andotra N, Gupta R (2016) Impact of environmental turbulence on market orientationbusiness performance relationship in SSIs. Global Business Review 17(4):806-820.

Ansari S, Bell J, Okano H (2007) Target costing: Uncharted research territory. In: Chapman CS, Hopwood AG, Shields MM (ed) Handbook of Management Accounting Research Vol. 2. Elsevier, Amsterdam et al., pp 507-530. 
Atkinson AA, Kaplan RS, Matsumura EM, Young SM (2012) Management accounting: Information for decision-making and strategy execution, 6th edn. Pearson, New Jersey.

Ax C, Greve J, Nilsson U (2008) The impact of competition and uncertainty on the adoption of target costing. International Journal of Production Economics 115(1): 92-103.

Axelsson B, Laage-Hellman J, Nilsson U (2002) Modern management accounting for modern purchasing. European Journal of Purchasing \& Supply Management 8(1):53-62.

Bauer HH, Herrmann A, Mengen A (1994) Eine Methode zur gewinnmaximalen Produktgestaltung auf der Basis des Conjoint Measurement. Journal of business economics 64(1):81-94.

Bastl M, Grubic T, Templar S, Harrison A, Fan I-S (2010) Inter-organisational costing approaches: The inhibiting factors. The International Journal of Logistics Management 21(1):65-88.

Baykasoğlu A, Kaplanoğlu V (2007) A service-costing framework for logistics companies and a case study. Management Research News 30(9):621-633.

Bayou ME, Reinstein A (2004) Accounting for cost interactions in designing products. In: Epstein M, Malina MA (ed) Advances in management accounting. Emerald Group Publishing Limited, Bingley, pp 151-170.

Becker W, Baltzer B, Ulrich P (2014) Wertschöpfungsorientiertes Controlling: Konzeption und Umsetzung. Kohlhammer, Stuttgart.

Betz S (1998) Zielkostenplanung und -kontrolle auf Basis der Erfahrungskurve. Zeitschrift für Planung 9(3):249-268.

Bohrl K, Listl A (1999) Preisuntergrenzenermittlung und Target Costing. In: Altenburger OA, Janschek O, Müller H (ed) Fortschritte im Rechnungswesen. Gabler, Wiesbaden, pp 241277.

Brühl R (1996) Die Produktlebenszyklusrechnung zur Informationsversorgung des Zielkostenmanagements. Zeitschrift für Planung 7(4):319-335.

Brühl R (2010) Kennzahlen für die Zielkostenkontrolle. Zeitschrift für Planung \& Unternehmenssteuerung 21(1):117-128.

Brünger C, Faupel C (2010) Target Costing: Pragmatische Ansätze für eine erfolgreiche Anwendung. Controlling \& Management 54(3):170-174.

Burritt RL, Schaltegger S (2014) Accounting towards sustainability in production and supply chains. The British Accounting Review 46(4):327-343. 
Cadez S, Guilding C, (2008) An exploratory investigation of an integrated contingency model of strategic management accounting. Accounting, Organizations and Society 33(7-8): 836-863.

Chen YSA, Romocki T, Zuckerman GJ (1997) Examination of U.S.-based Japanese subsidiaries: Evidence of the transfer of the Japanese strategic cost management. The International Journal of Accounting 32(4):417-440.

Chenhall RH (2003) Management control systems design within its organizational context: findings from contingency-based research and directions for the future. Accounting, Organizations and Society 28(2-3): 127-168.

Chwolka A (2003) Marktorientierte Zielkostenvorgaben als Instrument der Verhaltenssteuerung im Kostenmanagement. Zeitschrift für betriebswirtschaftliche Forschung 55(3):135157.

Cinquini L, Collini P, Marelli A, Tenucci A (2015) Change in the relevance of cost information and costing systems: evidence from two Italian surveys. Journal of Management \& Governance 19(3): 557-587.

Cinquini L, Tenucci A (2010) Strategic management accounting and business strategy: A loose coupling? Journal of Accounting \& Organizational Change 6(2):228-259.

Coenenberg AG, Fischer T, Schmitz J (1994) Target Costing und Product Life Cycle Costing als Instrumente des Kostenmanagements. Zeitschrift für Planung 5(1):1-38.

Cooper R (1996) Lean enterprises and the confrontation strategy. Academy of Management Executive 10(3):28-39.

Cooper R, Slagmulder R (1997) Target costing and value engineering. Productivity Press, New Jersey.

Cooper R, Slagmulder R (1999) Develop profitable new products with target costing. Sloan Management Review 40(4):22-33.

Cooper R, Slagmulder R (2004) Interorganizational cost management and relational context. Accounting, Organizations and Society 29(1):1-26.

Cooper R, Yoshikawa T (1994) Inter-organizational cost management systems: The case of the Tokyo-Yokohama-Kamakura supplier chain. International Journal of Production Economics 37(1):51-62.

DeLone W, McLean E (1992) Information Systems Success: The quest for the dependent variable. Journal of Management Information Systems 3(4):60-95. 
Demski JS, Feltham GA (1976) Cost determination: A conceptual approach. lowa State University Press, Ames.

Dittmar J (1996) Konzeptioneller Weiterentwicklungsbedarf bei der Zielkostenplanung. Zeitschrift für Planung 7(2):181-192.

Dugal M, Gopalakrishnan S (2000) Environmental volatility: A reassessment of the construct. The International Journal of Organizational Analysis 8(4):401-424.

Ehrlenspiel K, Kiewert A, Lindemann U, Mörtl M (2014) Kostengünstig Entwickeln und Konstruieren: Kostenmanagement bei der integrierten Produktentwicklung, 7th edn. Springer Vieweg, Heidelberg.

El Kadiri S, Grabot B, Thoben KD, Hribernik K, Emmanouilidis C, von Cieminski G, Kiritsis D (2016) Current trends on ICT technologies for enterprise information systems. Computers in Industry 79(1):14-33.

Ellram LM (1996) A structured method for applying purchasing cost management tools. International Journal of Purchasing and Materials Management 32(4):11-19.

Ernst C, Schenk G, Schuster P (2009) Kostenrechnung: Schnell erfasst. Springer, Heidelberg.

Everaert P, Bruggeman W (2002) Cost targets and time pressure during new product development. International Journal of Operations \& Production Management 22(12): 1339_ 1353.

Everaert P, Loosveld S, van Acker T, Schollier M, Sarens G (2006) Characteristics of target costing: Theoretical and field study perspectives. Qualitative Research in Accounting \& Management 3(3):236-263.

Everaert P, Swenson DW (2014) Truck redesign case: Simulating the target costing process in a product design environment. Issues in Accounting Education 29(1):61-85.

Ewert R (1997) Target Costing und Verhaltenssteuerung. In: Götze U, Ruch B, Weber J (ed) Kostenmanagement: Aktuelle Konzepte und Anwendungen. Springer, Heidelberg, pp 299-321.

Ewert R, Ernst C (1999) Target costing, coordination and strategic cost management. European Accounting Review 8(1):23-49.

Ewert R, Wagenhofer A (2014) Interne Unternehmensrechnung, 8th edn. Springer, Heidelberg.

Fischer JO (2008) Kostenbewusstes Konstruieren: Praxisbewährte Methoden und Informationssysteme für den Konstruktionsprozess. Springer, Heidelberg. 
Fischer TM, Schmitz J (1994) Zielkostenmanagement. Die Betriebswirtschaft 54(3):417-420.

Flik M, Heering C, Kampf H, Staengel D (1998) Neugestaltung des Entwicklungsprozesses bei einem Automobilzulieferer: Prozeßorientierte Reorganisation, Quality Function Deployment und Target Costing. Zeitschrift für betriebswirtschaftliche Forschung 50(3):289-305.

Franz K-P (1993) Target Costing: Konzept und kritische Bereiche. Controlling 5(3):124-130.

Freidank C-C, Zaeh P (1997) Spezialfragen des Target Costing und des Kostenmanagements. In: Freidank C, Götze U, Ruch B, Weber J (ed) Kostenmanagement: Aktuelle Konzepte und Anwendungen. Springer, Heidelberg, pp 233-274.

Fullerton RR, McWatters CS (2004) An empirical examination of cost accounting practices used in advanced manufacturing environments. Advances in Management Accounting 12(1):85-113.

Gagne ML, Discenza R (1995) Target costing. Journal of Business \& Industrial Marketing 10(1):16-22.

Gehrig M, Breu M (2013) Controlling hilft, strategische Denkfehler zu vermeiden. Controlling \& Management Review 57(3):46-53.

Gopalakrishnan M, Libby T., Samuels JA, Swenson D (2015) The effect of cost goal specificity and new product development process on cost reduction performance. Accounting, Organizations and Society 42: 1-11.

Götze U (1993) ZP-Stichwort: Target Costing. Zeitschrift für Planung 4(4):381-389.

Götze U (2010) Kostenrechnung und Kostenmanagement, 5th edn. Springer, Heidelberg.

Götze U, Linke C (2008) Interne Unternehmensrechnung als Instrument des marktorientierten Zielkostenmanagements: Ausgewählte Probleme und Lösungsansätze. Zeitschrift für Planung \& Unternehmenssteuerung 19(1):107-132.

Heirati N, O'Cass A, Schoefer K, Siahtiri V (2016) Do professional service firms benefit from customer and supplier collaborations in competitive, turbulent environments? Industrial Marketing Management 55(1):50-58.

Hevner AR, March ST, Park J, Ram S (2004) Design science in information systems Research. Management Information Systems Quarterly 28(1):75-105.

Hibbets AR, Albright T, Funk W (2003) The competitive environment and strategy of target costing implementers: Evidence from the field. Journal of Managerial Issues 15(1):65-81. 
Hoffjan A (1994) Strategisches Zielkostenmanagement für öffentliche Investitionen: Darstellung und kritische Analyse am Beispiel eines Parkhauses. Zeitschrift für öffentliche und gemeinwirtschaftliche Unternehmen 17(1):24-38.

Horváth P (2012) Volatilität als Effizienztreiber des Controllings. Controlling \& Management $56(3): 31-36$.

Horváth P, Gleich R, Seiter M (2015) Controlling, 13th edn. Vahlen, München.

Hung K-P, Chou C (2013) The impact of open innovation on firm performance: The moderating effects of internal R\&D and environmental turbulence. Technovation 33(10-11):368380 .

Hyvönen J (2005) Adoption and benefits of management accounting systems: Evidence from Finland and Australia. Advances in International Accounting 18(1):97-120.

Ibusuki U, Kaminski PC (2007) Product development process with focus on value engineering and target-costing: A case study in an automotive company. International Journal of Production Economics 105(2):459-474.

ICV (2013) Was macht Controller erfolgreich(er)? Auf das Verhalten kommt es an. Internationaler Controller Verein e.V., Wörthsee.

Jack L, Jones JVH (2008) Facing up to new realities: The case for using relevant cost and target cost approaches in agriculture. Journal of Applied Accounting Research 8(3):116145.

Jahn D, Krystek U (2003) Target Costing als Ansatz einer marktorientierten Reorganisationsplanung. Zeitschrift für Planung 14(1):51-74.

Jander H, Kahlenberg R, Graßhoff J (2006) Gewährleistungsmanagement im Entstehungszyklus eines Fahrzeugs: Weiterentwicklung des Target Costing-Konzeptes bei BMW Motorrad. Zeitschrift für betriebswirtschaftliche Forschung 58(1):128-148.

Kajüter P (2005) Kostenmanagement in der deutschen Unternehmenspraxis: empirische Befunde einer branchenübergreifenden Feldstudie. Schmalenbachs Zeitschrift für betriebswirtschaftliche Forschung 57(1): 79-100.

Kajüter P (2013) Target Costing: Market-driven cost management. In: Mitchell F, Nørreklit H, Jakobsen M (ed) The Routledge Companion to Cost Management. Routledge, New York, pp 82-95.

Kaplan RS, Cooper R (1998) Cost \& effect: Using integrated cost systems to drive profitability and performance. Harvard Business Press, Boston. 
Kato Y (1993) Target costing support systems: Lessons from leading Japanese companies. Management Accounting Research 4(1):33-47.

Kee R (2010) The sufficiency of target costing for evaluating production-related decisions. International Journal of Production Economics 126(2):204-211.

Kee R, Matherly M (2006) Decision control of products developed using target costing. In: Epstein MJ, Lee JY (ed) Advances in Management Accounting. Emerald Group Publishing Limited, Bingley, pp 267-292.

Kieser A (2014) Der Situative Ansatz. In: Kieser A, Ebers M (ed) Organisationstheorien, 7th edn. Kohlhammer, Stuttgart, pp 164-194.

Kocsoy M, Gurdal K, Karabayir ME (2009) Target costing in Turkish manufacturing enterprises. Problems and Perspectives in Management 7(1):197-207.

Koonce DA, Gandhi RP, Nambiar AN, Judd RP (2007) Identifying and removing error in hierarchical cost estimates. International Journal of Production Economics 109(1-2):41-52.

Krapp M, Wotschofsky S (2000) Stochastisches Target Costing. Zeitschrift für Planung 11(1):23-40.

Kremin-Buch B (2007) Strategisches Kostenmanagement: Grundlagen und moderne Instrumente, 4th edn. Gabler, Wiesbaden.

Kulmala HI, Paranko J, Uusi-Rauva E (2002) The role of cost management in network relationships. International Journal of Production Economics 79(1):33-43.

Küpper H-U, Friedl G, Hofmann C, Hofmann Y, Pedell B (2013) Controlling: Konzeption, Aufgaben, Instrumente, 6th edn. Schäffer-Poeschel, Stuttgart.

Lamming R (2000) Japanese supply chain relationships in recession. Long Range Planning 33(6):757-778.

Locke EA (1968) Toward a theory of task motivation and incentives. Organizational Behavior and Human Performance 3(2):157-189.

Locke EA, Latham GP (2002) Building a practically useful theory of goal setting and task motivation: A 35-year odyssey. American Psychologist 57(9):705-717.

Maas K, Schaltegger S, Crutzen N (2016) Integrating corporate sustainability assessment, management accounting, control, and reporting. Journal of Cleaner Production 136(10):237-248.

Martinez Ramos M (2004) Interaction between management accounting and supply chain management. Supply Chain Management: An International Journal 9(2):134-138. 
Mclvor R (2001) Lean supply: The design and cost reduction dimensions. European Journal of Purchasing \& Supply Management 7(4):227-242.

McNair CJ, Polutnik L, Silvi R (2001) Cost management and value creation: The missing link. The European Accounting Review 10(1):33-50.

Michel U (2011) Entwicklungstrends und Excellence im Controlling. In: Horváth P (ed) Exzellentes Controlling, exzellente Unternehmensleistung: Best practice und Trends im Controlling. Schäffer-Poeschel, Stuttgart, pp 3-21.

Modarress B, Ansari A, Lockwood DL (2005) Kaizen costing for lean manufacturing: A case study. International Journal of Production Research 43(9):1751-1760.

Monden Y (1993) Japanese new-product development techniques. Journal of Industry Studies 1(1):43-49.

Monden Y, Akter M, Kubo N (1997) Target costing performance based on alternative participation and evaluation methods: A laboratory experiment. Managerial and Decision Economics 18(2):113-129.

Monden Y, Hamada K (1991) Target costing and kaizen costing in Japanese automobile companies. Journal of Management Accounting Research 3(1):16-34.

Mouck T (2000) Beyond Panglossian theory: Strategic capital investing in a complex adaptive world. Accounting, Organizations and Society 25(3):261-283.

Mouritsen J, Hansen A, Hansen, CØ (2001) Inter-organizational controls and organizational competencies: Episodes around target cost management/functional analysis and open book accounting. Management Accounting Research 12(2):221-244.

Nagasawa S (1997) Application of fuzzy theory to value engineering. Computers \& Industrial Engineering 33(3-4):565-568.

Newman RG, McKeller JM (1995) Target pricing: A challenge for purchasing. International Journal of Purchasing \& Materials Management 31(2):12-20.

Nicolini D, Tomkins C, Holti R, Oldman A, Smalley M (2000) Can target costing and whole life costing be applied in the construction Industry? Evidence from two case studies. British Journal of Management 11(4):303-324.

Nishimura A (2014) Transforming cost design into environmentally conscious cost design in Japan: Likelihood and problems for further development. Journal of Management Control 25(1):55-75.

Ossadnik W (2009) Controlling, 4th edn. Oldenbourg, München. 
Park SJ, Park WJ, Woo, S (2016) Implementation of automated systems for target cost management and assessing performance: a case study in a global automobile component company. Journal of Applied Business Research 32(3): 829-856.

Petter S, DeLone W, McLean ER (2013) Information systems success: The quest for the independent variables. Journal of Management Information Systems 29(4):7-62.

Pfaff D, Trossmann E (2016) Die Kosten- und Leistungsrechnung - Ein Blick auf mehr als 70 Jahre Vergangenheit und eine spannende Zukunft. Die Unternehmung 70(4):365-385.

Roslender R, Hart SJ (2002) Integrating management accounting and marketing in the pursuit of competitive advantage: The case for strategic management accounting. Critical Perspectives on Accounting 13(2):255-277.

Schaltegger S, Burritt, RL (2010) Sustainability accounting for companies: Catchphrase or decision support for business leaders? Journal of World Business 45(4):375-384.

Schäffer U (2016) Nachhaltiges Management: Eine Bestandsaufnahme aus der Perspektive des Controllings. In: Ahn H, Clermont M, Souren R (ed) Nachhaltiges Entscheiden: Beiträge zum multiperspektivischen Performancemanagement von Wertschöpfungsprozessen. Springer, Wiesbaden, pp 319-332.

Schäffer U, Bechtoldt C, Grunwald-Delitz S, Reimer T (2014a) Controlling-Kultur als Schlüssel im Umgang mit Volatilität. Controlling and Management Review 58(5): 62-69.

Schäffer U, Bechtoldt C, Grunwald-Delitz S, Reimer T (2014b) Steuern in volatilen Zeiten: Wie Unternehmenskultur und Instrumente zusammenspielen. Weinheim: Wiley-VCH.

Schäffer U, Botta J (2012) Hilfe, die Welt ist volatiler geworden! Implikationen für das Controlling. Controlling \& Management 56(2):8-12.

Schäffer U, Weber J (2012) Zukunftsthemen des Controllings. Controlling 24(2):78-84.

Schäffer U, Weber J (2015) Controlling im Wandel: Die Veränderung eines Berufsbilds im Spiegel der zweiten WHU-Zukunftsstudie. Controlling 27(3):185-191.

Schmeisser W, Bertram S (2008) Zur Integration des Target Costing und der Prozesskostenrechnung in den Berliner Balanced Scorecard Ansatz bei Entwicklungs- und Konstruktionsvorhaben in der Automobil- und Maschinenbauindustrie. In: Schmeisser W, Mohnkopf $\mathrm{H}$, Hartmann M, Metze G (ed) Innovationserfolgsrechnung: Innovationsmanagement und Schutzrechtsbewertung, Technologieportfolio, Target-Costing, Investitionskalküle und Bilanzierung von FuE-Aktivitäten. Springer, Heidelberg, pp 387-423.

Seal W, Berry A, Cullen J (2004) Disembedding the supply chain: Institutionalized reflexivity and inter-firm accounting. Accounting, Organizations and Society 29(1):73-92. 
Seidenschwarz W (2003) Target Costing. In: Diller H, Herrmann A (ed) Handbuch Preispolitik: Strategien - Planung - Organisation - Umsetzung Vol. 1. Gabler, Wiesbaden, pp 437-453.

Seidenschwarz W (2008) Die zweite Welle des Target Costing: Die Renaissance einer intelligenten Entwicklungsmethodik. Controlling 20(11):617-626.

Seidenschwarz W (2015) Profitable Hauptumsatzträger entwickeln: Target Costing in neuen Kundenwelten und veränderten Entwicklungslandschaften. Controlling 27(3):146-152.

Sénéchal O, Tahon C (1998) A methodology for integrating economic criteria in design and production management decisions. International Journal of Production Economics 5657(20):557-574.

Shank JK, Fisher J (1999) Case study: Target costing as a strategic tool. MIT Sloan Management Review 41(1):73-82.

Simon HA (1972) Theories of bounded rationality. In: McGuire CB, Radner R (ed) Decision and organization. North-Holland Pub. Co., Amsterdam, pp 161-176.

Song M, Im S, van der Bij H, Song LZ (2011) Does strategic planning enhance or impede innovation and firm performance? Journal of Product Innovation Management 28(4):503520.

Stair RM, Reynolds GW (2016) Fundamentals of information systems. Cengage Learning, Boston.

Staroßom H (2013) Corporate Finance Teil 2: Finanzierung in den Lebensphasen einer Unternehmung. Springer Gabler, Wiesbaden.

Steinhoff F, Trommsdorff V (2008) Conjointbasierte Messung von Nutzenbeiträgen von Produktfunktionen und Generierung von Zielpreisen (Target Pricing). In: Schmeisser W, Mohnkopf H, Hartmann M, Metze G (ed) Innovationserfolgsrechnung: Innovationsmanagement und Schutzrechtsbewertung, Technologieportfolio, Target-Costing, Investitionskalküle und Bilanzierung von FuE-Aktivitäten. Springer, Heidelberg, pp 371-385.

Taschner A (2015) Management reporting und behavioral accounting: Verhaltenswirkungen des Berichtswesens im Unternehmen. Springer Gabler, Wiesbaden.

van Rensburg DJ, Pretorius L (2014) Managing for volatility on technology projects: A conceptual model. Procedia - Social and Behavioral Sciences 110(1):40-51.

Varoutsa E, Scapens RW (2015) The governance of inter-organisational relationships during different supply chain maturity phases. Industrial Marketing Management 46: 68-82. 
Vilain M (2006) Finanzierungslehre für Nonprofit-Organisationen: Zwischen Auftrag und ökonomischer Notwendigkeit. VS Verlag für Sozialwissenschaften, Wiesbaden.

Wagenhofer A (1997) Kostenrechnung und Verhaltenssteuerung. In: Freidank CC, Götze U, Huch B, Weber J, Mikus B (ed) Kostenmanagement: Aktuelle Konzepte und Anwendungen. Springer, Berlin-Heidelberg, pp 57-78.

Weber J, Schäffer U (2014) Einführung in das Controlling, 14th edn. Schäffer-Poeschel, Stuttgart.

Weber J, Schäffer U, Goretzki L, Strauß E (2012) Die zehn Zukunftsthemen des Controllings: Innovationen, Trends und Herausforderungen. Wiley, Weinheim.

Werner H (2014) Supply Chain Controlling: Grundlagen, Performance-Messung und Handlungsempfehlungen. Springer, Wiesbaden.

Windolph M, Moeller K (2012) Open-book accounting: Reason for failure of inter-firm cooperation? Management Accounting Research 23(1):47-60.

Woods M, Taylor L, Fang GCG (2012) Electronics: A case study of economic value added in target costing. Management Accounting Research 23(4):261-277.

Wouters M, Morales S, Grollmuss S, Scheer M (2016) Methods for cost management during product development: a review and comparison of different literatures. Advances in Management Accounting. Volume 26: 139-274.

Wouters M, Morales S (2014) The contemporary art of cost management methods during product development. Advances in Management accounting. Volume 24: 259-346.

Yalcinkaya G, Aktekin T, Yeniyurt S, Umar S (2017) How often should a firm modify its products? A Bayesian analysis of automobile modification cycles. Marketing Letters 28(1):8597.

Yasukata K, Yoshida E, Yamada I, Oura K (2013) A longitudinal case study of target cost management implementation at a shipbuilding company. Journal of Accounting and Organizational Change 9(4): 448-470.

Yazdifar H, Askarany D (2012) A comparative study of the adoption and implementation of target costing in the UK, Australia and New Zealand. International Journal of Production Economics 135(1):382-392.

Zhou H, Yang Y, Chen Y, Zhu J (2018) Data envelopment analysis application in sustainability: the origins, development and future directions. European Journal of Operational Research 264(1):1-16. 


\section{Cited sources}

Consideration of information uncertainty
Ehrlenspiel et al. (2014)

Götze and Linke (2008) Hoffjan (1994)

Koonce et al. (2007)

Krapp and Wotschofsky (2000)

Nagasawa (1997)

\begin{tabular}{l} 
Dynamic \\
target costs \\
\hline
\end{tabular}

Multi-periodic approach

Coenenberg et al. (1994)

Gopalakrishnan et al. (2015)

Brühl (1996)

Götze and Linke (2008)

Kee (2010)

Kee and Matherly (2006)

Mouck (2000)

Nicolini et al. (2000)

Woods et al. (2012)

$\begin{array}{lll}\text { Consideration } & \text { Baykasoğlu and Kaplanoğlu (2007) } \\ \text { of indirect } & \text { Bayou and Reinstein (2004) }\end{array}$

of indirect

costs

Götze (1993)

Hoffjan (1994)

Schmeisser and Bertram (2008)

Consistent

Götze and Linke (2008)

resource

allocation

\section{Achieved progress}

- Price-demand function or Conjoint+Cost to identify combination of cost information yielding maximum benefit

- Calibration and risk analysis to decrease degree of subjectivity within information

- Stochastic variables to direct attention towards decreasing standard derivation within information

- Fuzzy arithmetic to consider information fuzz- iness

- Either NPV or EVA to consider opportunity costs, interest effects and trade-off effects of payments

\section{Remaining tasks}

- Further methodological support to take account of information uncertainty

- Development of a dynamic target cost calculation process

- Coping with NPV supporting decisions to postpone payments, arguably at expense of product quality

- Coping with technical implementation challenges of EVA on product level

-ABC to manage indirect costs

- Methodological connection of target costing and $A B C$ to consider interdependencies

- Concise procedure on how to get from full target costs to decomposable target costs

- Holistic model that also integrates relevant indirect costs and basic needs 


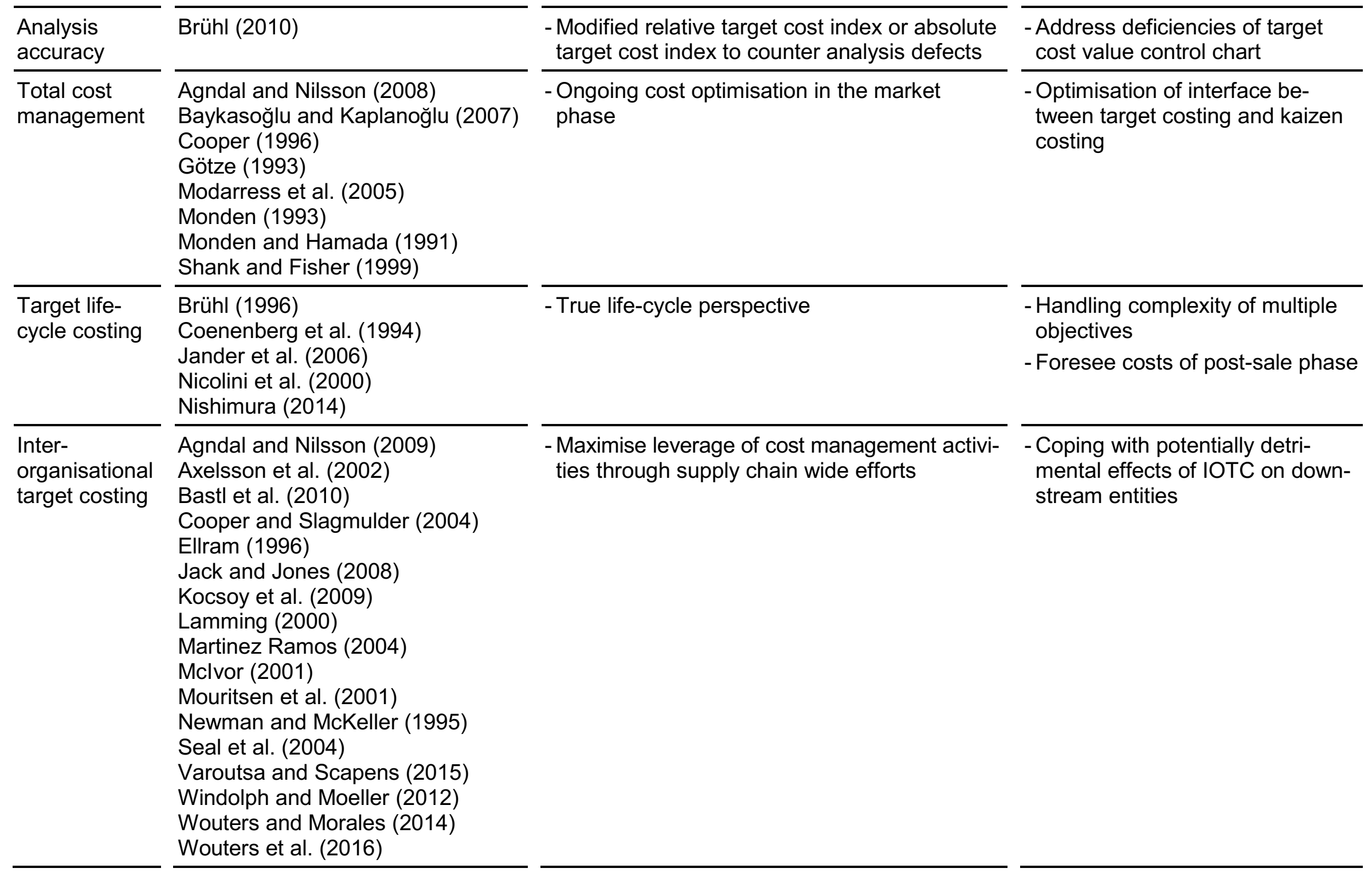

Table 1: The past and future of research on target costing's methodology 